\title{
The Philosophy of the Saints: Meditational Impact of Sufi Folklore on Human Beings
}

\author{
Sahibzada Sultan Ahmed Ali
}

\begin{abstract}
Sufi Saints are commonly referred to as highly virtuous individuals with a unique philosophy. Sufis across the world but primarily in Indo-Pak subcontinent and the Greater Middle East had a unique philosophy prioritizing the highest form of one's purity. Likewise, Sufis have various expressions through which they get their message across in different languages. They also channelize one of the most effective means of communication i.e. folklore and poetry in their respective language and culture to disseminate their philosophy. Sultan-ul-Ärifeen Sultan Bahoo (d. 1691) is one such example - who is well-known in the Punjab region of Pakistan due to his Punjabi poetry. His poetry has preserved not only the mystical experiences that he went through but has also preserved the folklore culture of Punjab having meditational impact on people, enabling them to transform themselves by bringing peace to their hearts, address their respective traumas and spread love. This paper focuses on how Sufi folklore in the form of language, melody and meditation practices helps human beings to counter their traumatic and distressful experiences which often lead to menaces such as bigotry and extremism. The paper applies the case study of Sultan Bahoo and argue how his poetry remained an effective source of meditation and aspiration for the individuals irrespective of their religion, ethnicity or caste. The paper will end by outlining suggestions on how challenges of trauma can be addressed through the meditational impact of Sufi poetry on people and their hearts.
\end{abstract}

Keywords - Mysticism, Sufism, Poetical Philosophy, Folklore, Trauma

\section{INTRODUCTION}

Like other forms of literature, poetry conveys ideas, offers vivid and unique description and expresses our inward spiritual, emotional and psychological states of personality [1]. Poetry pays particularly close attention to words themselves; their sounds, textures, patterns, and meanings. It takes special pleasure in focusing on the verbal music inherent in language. As William Wordsworth describes that poetry is natural flow of feelings which are originated from the calmness,

"Poetry is the spontaneous overflow of powerful feelings: it takes its origin from emotion recollected in tranquillity." [2]

Similarly, Percy Bysshe Shelley describes poetry as a collection of moments, which are collected from best and happiest life. Percy Bysshe Shelley says,

Sahibzada Sultan Ahmed Ali

Chairman, MUSLIM Institute, Islamabad

Pakistan
"Poetry is the record of the best and happiest moments of the happiest and best minds."[3]

Dual duty performed by Sufi poets is to be considered. On one hand preaching Islam to non-Muslims and on the other preaching Oneness and ardent love of Almighty to believers. The oneness impacting people in their both individual and social aspects alike is making it easier to reflect individual traits in social construct. Individual as well as social constructs both remained under mystics' focus. When individuals discover their spiritual destination, simultaneously through its reflection society finds its spiritual manifestation [4].

Sufi mystics reveal their calmness and best part of their life i.e., when they are in state of oneness with divine [5]. Shaykh Abdul Qādir Gīlānī (1166) - the founder of Qādiri order, who is also regarded as 'Saint of the Saints' - briefly elucidates Tasawuf with the following beautiful words,

"A Sufi is one who is able to find the path of Safaa (purification)". [6]

Shaykh Syed 'Alī al-Hujwīrī Dātā Ganj Bakhsh narrates, "Sufi is the one whose heart is pure from all kinds of impurities. The opposite of purity is rust." [7]

In Islamic literature, the spiritual and moral poetry of Saadi, Bahoo (d. 1691), Rumi (d. 1273), Sanā'ì (d. 1131), Attar (d. 1221), Khusrau (d. 1325), Iqbal (1938), and of many others are very much famous. English poetry especially paradise lost by Milton, Faerie queen by Edmund Spenser and metaphysical poetry by John Done are having mystical themes. These poets talked about God-Man-Nature nexus. They defined and revealed the secrets of divine love and their unique mystical experiences through their pens in the form of poetry. They have written their mystical experiences in respective native languages of their regions that is why we find variety of mystical literature in different languages.

From Arabia to Persia, Africa, Central Asia, South Asia, Far East, China, every region echoes with the voice and poetry of Sufi mystics. A Sufi mystic is a unique human being who experiences the highest state of oneness with the Divine [5]. Hassan al-Bașrī (d. 728), al-Sirrī Saqti (d. 867), Junayd alBaghdadi (d. 910), Abū Ḥāmid Imam Al-Ghazālī (d. 1111), Shaykh Abdul Qādir Gīlānī (d. 1166), Ibn 'Arabī (d. 1240), Mevlana Rumi (d. 1273), Baha-ud-Din Naqshband (d. 1389), Ḥāfez Shīrāzī (d. 1390), Sultan-ul-Ārifeen Sultan Bahoo (1691), Mīrzā Abdul-Qādir Bēdil (d. 1720) and uncountable such personalities in every part of Muslim world pronounce this fact. 
The paper contributes to the existing body of knowledge in the following ways. Firstly, it discusses the basic premises of Sufi meditational philosophy and how it has evolved over the centuries. Secondly, it discusses the role of Sufi folklore and meditation in mitigating international traumatic and conflicting conditions. Thirdly, the meditational philosophy of renowned Sufi saints has been discussed and analysed with respect to contemporary challenges of workplace spirituality, world peace, harmony, universal brotherhood, sustainable development and conflict resolution. Fourthly, this paper takes the meditational folklore and Abyāt of Sultan Bahoo as special case to discuss its theological and practical dimensions. Fifthly, the applications and implications of Sufi meditational literature have been discussed to identify the important contributions towards personal development, societal responsibilities, eradication of extremism, universal peace and sustainable development. Lastly, we have also discussed the application of Sufi medication in medical and psychological therapy as used in the world.

\section{THE FOLKLORE DOMAIN OF SAINT'S POETIC PHILOSOPHY}

Jonas Balys defines that folklore comprises traditional creations of people, primitive and civilized. These are produced by using sounds and words in metric form and prose, and include also folk beliefs or superstitions, customs and performances, dances and plays [8]. The beliefs, customs and traditions are passed on from generations onward. Much folklore consists of poetry, tales, legends with myths, superstitions, including religious celebrations carrying the societal norms and acquaintance [9]. People in rural areas usually don't have written scripts, but they have folk songs which they imitate from their forefathers as a trust and treasure. People used to learn them from their childhood especially laps of their mothers [10]. Today scholars consider them group of people who share at least common linkage and building factor (a significant bondage) which gave them a better survival value for a long time.

Saints' poetry carries a specialty that it embraced and used such means for diffusion of knowledge in societies which became reason to cherish their message. For example people used to listen folklores, melodies, music and got inspired towards folk-singers. On the occasion of annual funfairs or such gatherings, people were able to access singers singing the melodies. The goal of Qawwal's performance is to evoke spiritual enhancement among the listeners, leading to mystical arousal and even ecstasy,

"... his role is simply that of a mouthpiece. . . [Without] any personal share in the impact generated by his performance..." [11]

Sufis discovered that the music emerges from poetry. Therefore, in the first step they adopted poetry and produced such poetry for which music could be composed accordingly [12]. When one comes across their poetry, it is felt that it emerges from pen as well as from flute. Going through their poetry, it reveals that it is already moulded in music.
The mystics (Ārifs) promoted their message in folk languages. Sufis made their message part of folk's entertainment sources. They shaped a productive society which even found its entertainment engulfed with spiritual philosophy. Citing example of Indian sub-Continent, large chunk of its music owes its origin to Ameer Khusrau (d. 1325) [11]. People, even those unable to understand contents of lyrics of Qawwali, feel influenced by its impact because of Nizām al-Dīn Awliyā (d. 1325) and Mu'īn al-Dīn Chishtī (d. 1236) [11]. Sufi poetry became part of folk traditions and practical lives. People can neither extricate themselves from this philosophy nor do they want to do so because it is source of their spiritual satisfaction.

\section{Challenging Trauma: Role of Saint's Poetic PHILOSOPHY}

Trauma creates a speechless fright that divides or destroys identity [13]. In this age of conflicts and clashes, mystical literature should address psychological scars, sufferings and grief through its melodious nature. Meditation should answer unanswered questions and need for truth [14]. Moreover reconciliation and justice should be major subjects of our literature and discourses. Prior to modern technological advancement, literature was the sole source of opinion making and narrative building [15].

In this age of globalization, mystical literature in not limited by borders or to specific nations. Saints' poetic philosophy portrays deep-rooted culture of a society through words. Every language and literature addresses evil aspects of society to realize the essence of spiritual experiences. Iqbal and Rumi's poetry and their global recognition for the noble cause of liberty, harmony, self-actualization and socio-political transformation are worth mentioning here [16].

Another aspect of saints' poetical philosophy is to understand the difference between revolution and transformation. Revolution could be bloody like Arab Springs but transformation (through inner transformation) would be peaceful where human soul and mind penetrate slowly into the strong peaceful movement. Multi-lingual and multidimensional literature to counter the trauma caused by social evils and express the essence of spiritual experiences is the need of the hour.

Sources and techniques to constructivism and hybrid warfare are evolved from literature [17]. In this contemporary age, saints' poetical philosophy, that values peace, should be taught in every social sciences department as it enables students to understand the new lexemes, vocabularies, complex and broader theoretical frameworks to understand the conflict, its impact and evolve prospects to avoid similar conflict in future.

\section{Sultan Bahoo AND FolKLoRe In AByĀt-E-BaHOO: A CASE STUdY}

A born saint who with gifts of God; developed and became 'Sultan-ul-Ārifeen' to 'Sultan-ul-Faqr'. Sultan-ul-Ārifeen 
Sultan Bahoo belongs to the fertile land of Shorkot district Jhang the present day Punjab, Pakistan. Born in 1629 AD to a spiritual family of Awan tribe the non-Fatimid descendants of fourth Caliph Haḍrat Ali al-Murtaza, spent his childhood under spiritual supervision of his mother. Based upon intuitional instructions of Shaykh Abdul Qādir Gīlānī, made the pledge at the hands of Syed Peer Abdul Rāhmān Dehlvi; a Qãdiri spiritual mentor in Delhi [18]. The divine qualities he imparted to his folks with on coming generations regarding the purification of heart and soul. This promising personality after gaining spiritual maturity attained highest echelons which made him an authority to be 'mürshid' (spiritual mentor) for so many followers, that increased to such an extent that his personality influenced the Mughal King Aurengzeb Alamgir [19].

Sultan Bahoo in general public is famous by his Punjabi (Poetry) known as Abyāt-e-Bahoo. He gives his message in native language (as he belongs to Punjab region). His teachings in Punjabi Abyāt give us the idea that he talks about great level of spirituality [20], which is above than formal, legalistic, and institutionalized forms of religion but is optimistic form that enhances possibility of one's spiritual relation with God [21]. As Zafar describes about Sultan Bahoo's poetry in a message published in Mirrat-ul-Ärifeen International,

"His poetry is recited and sung in a traditional manner and his message is one of love, fraternity, tolerance, and pluralism for religio-socio existence." [22]

Ayyub says about Sultan Bahoo's poetry,

"Sultan Bahoo in his poetry has invited and guided those, who had lost their path to creator and gathered them... be Muslim nation in true spirit. Most of his poetry is strengthening our connection with Him... His poetry is not only a pinnacle of Sufi wisdom, it also enshrines antidote to the prevailing cynicism, uncertainty, pessimism, nihilism and consequent despair in the post-modern society that has lost its religious and spiritual bearings." [23]

Sultan Bahoo remains one of the prominent Sufi Mystics of Indo-Pak sub-Continent whose impact is felt across the world. Despite authoring around 140 Persian books [24] he remains famous for Punjabi poetical work, one of the reasons being the local language Punjabi is the more attractive for the villagers. Such strong was the attraction that Abyāt became worldwide renown with Sultan Bahoo's name [25]. Every single line of Abyāt describes the deep philosophy and meaning which reveal itself upon the reader and listener. Popular among the folks, Abyāt became part and parcel of their lives leaving deep impact on culture and traditions [25]-[26]. He has presented such strong concepts in very easy way that became part and parcel of folklores and even modern day scholars name the translations of Abyāt of those concepts like 'Death Before Dying' [21] and 'Heart Deeper than Ocean' [25].

There are different themes in Abyät-e-Bahoo which are not limited to connection to the Creator, love of Holy Prophet ( $\square$ ), dhikr (remembrance), ishq (adherent love), purification of heart, death before dying, immortality of soul, "Hoo" as code of life, knowledge of reality, strong character and morality, forgiveness, patience and brotherhood.

\section{V.CONCEPT OF HOO}

When we talk about Sultan Bahoo and his Punjabi poetry, the discussion revolves around 'Hoo'. Meditational impact of Abya $\bar{t}$ starts from the concept of Hoo. Hoo has always been considered by Sufis as the excellence of the status of ' $Z a t$ ', the Almighty [27]. Ism-e-Zat, the actual name of Allah Almighty is described in four stages by Sufis هُو، لئ، لله، الله Hoo is the excellence as the Ayat-al-Kursi describes in Al-Qur'ān,

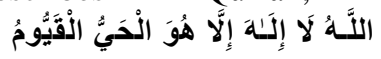

The last part of Surah AlHashr in Al- Qur'ān reads,

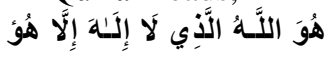

'Hoo' manifests the notion that there is only one 'He' everything else is deemed to annihilation. Sufi doesn't see anything but 'Hoo'. The meaning of 'Ba-Hoo' is analogous that such a personality which is always with 'Hoo' and for him there is nothing else meaningful and existent in front of 'Hoo'. In continuity the Sufis have described 'Hoo' as the ultimate and final destination. This concept encourages Muslims to struggle and strive for Divine attributes beyond mere materialism. Imam Fakhr al-Dīn al-Rāzì (d. 1210) explains [28],

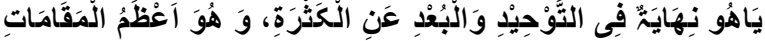

"Ya-Hoo is the ultimate status of Oneness. It is away from duality and is the greatest stage of Oneness."

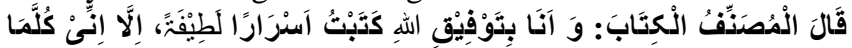

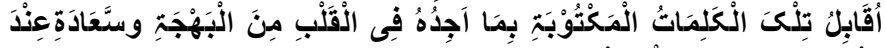

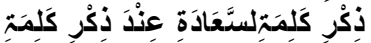

Al-Rāzī says that he has described many secrets with kind blessings of Almighty, tremendous delicate, intuitions and many secrets and mysteries of Almighty but his heart never received such observations and blessings which Almighty blessed on remembrance of Ya-Hoo.

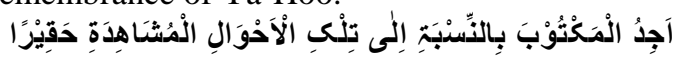

"I find this writing very minute in front of what I have experienced, what is revealed upon me by remembering Hoo, I didn't have anything in its comparison and even do not have the words for its description."

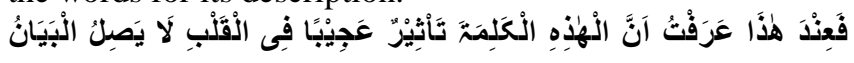

"It made me feel that this name provided me with very strange effects, the inexpressible." [28]

Shaikh Ibn-e-Taymiyyah [29] describes in the continuity of a quote by Sheikh Shīblī (d. 946),
لِلْعَارِفِيْنَ وَ

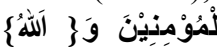

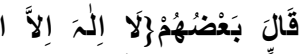

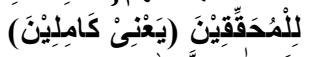

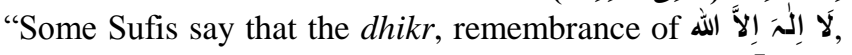
is initial stage specific for the believers. The dhikr of Arifeen is Allah and the dhikr of Hoo is for the perfect ones."

Abū Ḥāmid Imam Al-Ghazālī (d. 1111) writes [30],

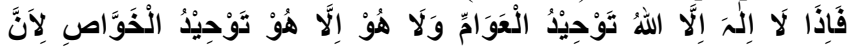




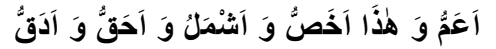

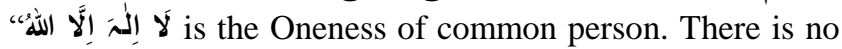
one but 'Hoo' only that Zat (Almighty) 'Hoo' is the oneness of select comprising of most generalized, most realistic and most sophisticated."

The emphasis laid by Sultan Bahoo on 'Hoo' reveals height of his discussion, the excellence of spirituality and faqr. Listener of his folklore poetry first considers 'Hoo' in poetical rhyme but is well taken to the similar condition that he feels its impact.

Hoo is also self-teaching very much connected to respiration through 'just heart' rather than normal ants-palimony breathing. One controls the breath rather than world controls one. The desire of exploration to very closer relation to nature brings one closer to the concept of controlling one's breath and desires. The meditation of this phenomenon will give a person complete mastery over evil design and satanic schemes. These efforts further develop a medium to mediate with Him forever. The fraternity friendship with Allah Almighty will endow protection and refuge from strong irresistible forces, whereas satanic evil domain will pursue one with better fortune hope of a promising attractive World. The propagation of superb 'sultanic faqr' is the spiritual symbolism of Sultan Bahoo which is very much in signification which is very much manifested as (Allah-Hoo) or (Ba-Hoo) 'Always with Hoo' an association of soul, spiritual (monolithic) actions of complete submission just for 'His pleasure'. In his Abyāt, Sultan Bahoo describes,

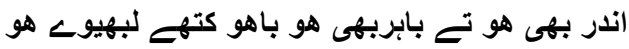 Hoo" \\ "Andar bhi Hoo tey Bahir bhi Hoo, Bahoo kithy Labhiwey}

"Hoo is inner and Hoo is in outer, from where Hoo could be accessed Hoo" [25].

The potential composition of Abyāt specifies meditationalmediation of dhikr (remembrance). Reflection is an integral part of repeated reminders with resonance of Allah 'Zat' or essence with attributes of reverence-enhancement of spiritual system.

"Hoo is in inner and Hoo in outer it scalds with every breath Hoo" [25].

The rhythm and rhyme of Hoo made his poetry part of folklores and music which further enhanced its impact and recognition. The translator of 'Death before dying' describes this reality when he acknowledges his mother for introducing him with Punjabi lyrics and Ustad Pathana Khan with Sultan Bahoo [21]. The deep-rooted philosophies penetrated the societies in conscious as well as subconscious level.

Poetical philosophy (including singing improvisations) profusely illustrates the fathomless concepts with a unique, unparalleled influence of Qur'ān and sunnah. This derivation of poetic literature imparts the listener a message of Islam in his own language with comprehensive connotation of code of conduct.

The 'flute' resonance gives him a fascinating 'melodious harmony' which further enhances the concept of 'fragrance' the flower garden of spiritualism. When poetic philosophy progresses a man towards higher stages of spiritual philosophy the achievements turn into accomplishment of success, progress, prosperity in both the worlds. The teachings of Sufi mystics should be spread to bring everlasting love and peace in the society. Because, Sufi poetry eradicates negative forces such as trauma, radicalization, and extremism and brings peace in inner self etc.

\section{PRACTICAL APPLICATION AND IMPLICATIONS OF SUFI MEDITATIONAL FOLKLORE}

Sufi meditation in the form of poetic literature and folklore has universal appeal to individuals and has profound impact on human beings all over the world. In the contemporary world of religious, racial, ethnic and political conflicts, Sufi meditational work could be a beneficial instrument for improving organizational practices and transnational challenges of creating harmony, peace and sustainable development. As [31] argue that Sufi meditational philosophy and its application has immense potential to provide us with a transformational imaginary to restructure our organizations, societies and individuals by conveying the world the universal message of divine love, brotherhood and peace. Therefore, such meditation has important implications for organizations and emphasize upon the role of spiritual leadership in improving workplace spirituality, business ethics and corporate social responsibility which results in increased levels of organizational commitment and employees productivity [32]. Moreover, Sufi mediation conducted under spiritual leadership foster work motivation, inspiration, employees' productivity, organizational performance and commitment, based on vision and culture of altruism, transcendence and interconnectedness with the work and the universe; such spiritual values actually provides more competitive advantage for organizations [33].

Workplace spirituality is considered to promote the values such as compassion, sense of right livelihood, work as a divine duty and form of meditation, selfless service, understanding and respecting diversity and pluralism [34]. Since Sufi folklore emphasizes upon such values through awakening of inner conscience and self-actualization under the training of spiritual leader, it could have long-lasting effect not only on personal development but also on societal values, norms and culture resulting in sustainable development [31],[35].

By promoting the sense of self-accountability, voluntary simplicity and optimal use of resources, spiritual and sustainable lifestyles, Sufi meditation could positively affect the sustainable economic and environmental development [35]. Therefore, spiritual meditation has strong linkage with the sustainability and the success in the long-run keeping in view the rising ecological and environmental issues due to excessive use of resources. Therefore, new terms such as ecospirituality, sustainable leadership, spiritual leadership and ecologism are rising at the scene, which require promoting workplace spirituality and ideas of corporate social 
responsibility as supported by Sufi meditational philosophy.

Sufi meditational philosophy is normally perceived to be applicable to spiritual growth but it has also become an effective tool for improving mental and physical health by doing regular meditation. In a recent medical research, [36] report that long-term meditators have lower chances of diseases such as heart attack, blood pressure, insomnia, chronic pain, cancer and various types of traumas because Sufi meditation actually provide positive benefits such as more concentration and insight, feeling more loving, positive and peaceful and such meditation practices result in secretion of more dehydroepiandrosterone (DHEA) hormone which reduces depression and anxiety, improve memory, weight reduction and overall good health.

Sufi meditation has a long history and it has been used as psychotherapy to treat chronic stress and acute nature of trauma. In a recent medical research on eye movement desensitization and reprocessing (EMDR) therapy, [37] suggest that the application of Sufi meditation could have substantial impact on psychological trauma cases and help people recover from emotional distress caused by devastating life experiences. Hence, Sufi meditation has very positive effect on stress reduction and drug addiction, it refreshes the mind and body, brings real happiness and mitigate emotional problems and worldly worries [38]. In an empirical research, [39] compared the use of Sufi meditation and mindful meditation in the treatment of 200 female patients having neurotic anxiety disorder. Their results indicate that Sufi meditation has been more effective than mindful meditation in reducing female anxiety as measured by Hamilton Anxiety Scale because it matches the beliefs of Muslim population.

\section{CONCLUSION}

Purification of heart and controlling desires with meditational impact of folklore poetry of Sufi Saints is what we deduce from Sufi mystic's poetry. The control over social evils becomes easier and paving the way for peace loving societies. Self-accountability to the accountability of universe are lessons from mystical poetry. Man's success, failure, prosperity, bankruptcy would depend upon keeping his soul pure or corrupting it.

Sultan Bahoo's poetry is an integral part of Sufi literature that reveals the idea of reaching the divine presence and Oneness with divine. Through his poetry we come to know that the path that leads to the divine starts from love of God and purification of heart by contemplating the actual name of God. It shows that according to the mystical way nothing other than divine reality can be called the absolute reality.

Sultan Bahoo's Abyāt teach that a mystic is not an ordinary person because he is united with divine all the time. He is no more an evil-self because he is transformed into divine reflection. According to all mystics, heart is the real source of divine knowledge and the way to attain divine-presence. Mystics are men with living hearts, who have attained divine presence from their hearts. The notion of unconditional love for God is the heart of mysticism. [40] says that the Sufis believe in the "higher and subtle truths of Sufism, or the "mysteries of divine love'," which are "revealed to the accomplished Sufi masters are essentially incommunicable,", but to achieve this spiritual union or the unitive experience the heart and soul needs to be cleansed of all impurities. These concepts are found to be embedded in the Punjabi Abyāt of Sultan Bahoo.

Sultan Bahoo repeats in his poetry the message of Allah Almighty that God is more near to him than his own jugular vein. He believes in reaching to divine-presence by love. When, one finds divine-presence he becomes more loving, caring and peaceful towards humanity. Lovers of God, who are gone in the ocean of unity with divine, are the happiest, kind and loving people. They enjoy the felicity of living in an ever green garden of divine blessings. Main theme of Sultan Bahoo's poetry is reaching the divine-presence which can only be attained through a heart that is pure and is willing to give up the material world for the love of God. God according to Sufi philosophy is not to be found in faraway places, one need only to look into his own heart and he shall find Him, for as Sultan Bahoo says that the heart is deeper than the oceans. This kind of self-actualization through Sufi meditation has been leading humans towards inner-peace and hence peace in society. Same is necessary in modern world in order to overcome trauma and to overcome all kinds of negative forces.

\section{REFERENCES}

[1] G. M. A. Grub, ed. On Poetry and Style. Hackket Publication Company: USA, 1989.

[2] Literary Articles. 2012 [cited August 28, 2019]; Available from: http://www.literary articles.com/2010/02/what-does-wordsworth-meanby.html

[3] Enotes. n.d [cited 28 August 2019]; Available from: https://www.enotes.com/topics/defence-poetry/quotes

[4] A. Shahnawaz, Conspiracy of Clash of Civilizations and teachings of Hadrat Sultan Bahoo, n.d. [cited 2019 September 3, 2019,]; Available from: http://www.alfaqr.net/en/clash-of-civilizations

[5] W.C. Chittick, Sufism: A Beginner's Guide, Oneworld Publications, 2000

[6] A. Q. Gīlān̄i, Sirr-ul-Asrar Fi Maa Yahtaj Ilaihil Abrar, Lahore: AlArifeen Publications, 2007.

[7] A. Hujwīrī, Kashf-ul-Mahjoob, Lahore: Maktaba Shams o Qamar, 2012.

[8] L. Leach, Definitions of Folklore. Journal of Folklore Research, vol. 33(3), 1996, pp. 255-264.

[9] A. John, My Neighbour's Faith: Islam Explained for African Christians, Nairobi: Hippo Book, 2008.

[10] Margaret A. Mills, Poetry and Mysticism in Islam: The Heritage of Rumi, Cambridge University, 1996.

[11] H. S. Powers and R. B. Qureshi, "Sufi Music of India and Pakistan. Sound, Context and Meaning in Qawwali," Journal of the American Oriental Society, Vol. 109(4), 1989, pp. 702-705. https://doi.org/10.2307/604123

[12] A. Waqar, "The "Lover "Archetype in Punjabi Classical Poetry," Pakistan Journal of History and Culture, vol. XXX (1), 2009, pp. 131158.

[13] M. Balaev, "Trends in Literary Trauma Theory," Mosaic. An Interdisciplinary Critical Journal, vol. 41(2), 2008, pp. 149-166.

[14] W. C. Chittick, The Self-Discourse of God; Principles of Ibn Al-Arabi's Cosmology, Lahore: Suhail Academy, 2006.

[15] T. Risse-Kappen, "Public Opinion, Domestic Structure, and Foreign Policy in Liberal Democracies," World Politics, vol. 43(4), 1991, pp. 479-512.

https://doi.org/10.2307/2010534 
[16] A. C.Kafka, Rumi: America's Favorite Poet, from Persia, with Love. 2017, [cited 2019 September 1, 2019]; Available from: https://www.washingtonpost.com/entertainment/books/rumi-americasfavortie-poet-from-persia-with-love/2017/01/17/240ccc82-d77f-11e69f9f-5cdb4b7f8dd7_story.html.

[17] L. M. Herța, "Russia's Hybrid Warfare-Why Narratives and Ideational Factors Play a Role in International Politics," Modelling the New Europe. An On-line Journal, vol. 21, 2016, pp. 52-76.

[18] M. I. M. Garcia, "Channels of Knowledge Transfer of Sultan Bahoo's Teachings in Modern Era," MUSLIM PERSPECTIVES Journal, vol. II(3), 2017, pp. 62-89.

[19] I. K. Niazi, Aurangzeb Alamgir and Creation of Pakistan. 2019 [cited September 5, 2019]; Available from: https://www.mirrat.com/article/61/694.

[20] T. Aamir, Views of Hadrat Sultan Bahoo on moral development in social perspectives. 2011 [cited September 20, 2019]; Available from: https://www.sultanbahoo.net/blog/views-of-Hadirat-sultan-bahoo-onoral-development-in-social-perspectives/.

[21] J. J. Elias, ed. Death before Dying. The Sufi Poems of Sultan Bahoo, University of California Press: London, 1998.

[22] S. M. Zafar, Mirrat-ul-Arifeen International, May, 2011, pp. 770-771, ch. Messages

[23] M. Ayyub, Mirrat-ul-Arifeen International, May, 2011, pp. 771-772, ch. Messages.

[24] H. S. Ahmad, ed. Divan-e-Bahu, Na'shad Publishers: Lahore, 1998.

[25] S. Bahoo, Sultan Bahoo: Heart Deeper than Ocean, Z. A. Awan Trans., Lahore: Al-Arifeen Publications, 2017.

[26] Z. A. Awan, Sultan Bahoo: A Living Legacy, Lahore: Al-Arifeen Publications, 2019

[27] M. A. Rahbeen, Comparative Study of Haḍrat Sultan Bahoo. in International Hadrat Sultan Bahoo Conference,. Islamabad: MUSLIM Institute, 2013.

[28] F. A. D. al-Rāzī, Al-Tafsir al-Kabir aw Mafatih al-Ghayb, Beirut, Lubnan: Dar al-Kutub al-'Ilmiyyah, vol. 1, 2013, pp. 124-124.

[29] T. A. Ibn Taymiyyah, Majmua'ah Fatawa Shiekh Al-Islam Ibn Taymiyyah, Peshawar, Pakistan: Kutab Khana Rasheedia, vol. 10, n.d. p. 279.

[30] A. H. M. Al-Ghazālī, Mishkāt al-anwār In Majmu'at rasa'il. Lebanon, Beirut: Dar al-Kutub al- 'Ilmiyyah, 2011, p. 14.

[31] S. Ul-Haq and F. R. Khan, A Sufi View of Human Transformation and Its Organizational Implications, Handbook of Personal and Organizational Transformation, 2018: p. 833-865. https://doi.org/10.1007/978-3-319-66893-2_45

[32] L. W. Fry, "Toward a theory of spiritual leadership," The leadership quarterly, vol. 14(6), 2003, pp. 693-727. https://doi.org/10.1016/j.leaqua.2003.09.001

[33] L. W. Fry and J. W. Slocum Jr., "Maximizing the triple bottom line through spiritual leadership," Organizational dynamics, vol. 37(1), 2008, pp. 86-96. https://doi.org/10.1016/j.orgdyn.2007.11.004

[34] D. W. McCormick, "Spirituality and management," Journal of managerial psychology, vol. 9(6), 1994, pp. 5-8. https://doi.org/10.1108/02683949410070142

[35] C. G. Beehner, Spirituality, Sustainability, and Success, Springer, 2019 pp. 219-241. https://doi.org/10.1007/978-3-319-77806-8 9

[36] S. Loue and M. Sajatovic, Encyclopedia of Women's Health, 2004, pp. 802-804. https://doi.org/10.1007/978-0-306-48113-0

[37] W. K. Abdul-Hamid and J. H. Hughes, "Integration of Religion and Spirituality Into Trauma Psychotherapy: An Example in Sufism?," Journal of EMDR Practice and Research, vol. 9(3), 2015, pp. 150-156. https://doi.org/10.1891/1933-3196.9.3.150

[38] M. S. Y. Abdullah, A. S. Bin Rosman and M. H. Mia, "Science and theology through sufism among malay drug addicts," European Journal of Science and Theology, vol. 14(3), 2018, pp. 137-146.

[39] L. Gul and S. F. Jahangir, "The Effectiveness of Mindfulness-Based Stress Reduction Programme (MBSRP) and Sufi Meditation (SM) in the Treatment of Neurotic Anxiety among Females," FWU Journal of Social Sciences, vol. 13(1), 2019.

[40] T. Anjum, Bridal Symbolism in Sultan Bahoo's Poetry, in Sultan Bahoo Blog. 2013, from www.sultanbahoo.net

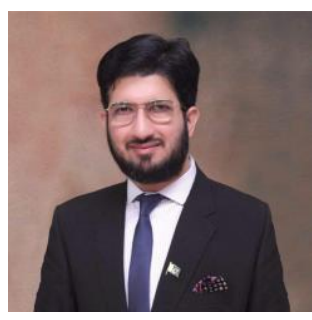

Sahibzada Sultan Ahmed Ali is Chairman of the research based think-tank MUSLIM Institute, Chairman Advisory Board of MUSLIM PERSPECTIVES Journal, Chief Editor of monthly magazine Mirratul-Ārifeen International, Chairman of AlĀrifeen Group of Publications \& AlĀrifeen Digital Production. He is from the tenth line among the descendent of Hadrat Sultan Bahoo, an eminent Sufi Saint of the sub-continent. He has visited different countries representing Institute and Pakistan; to participate in many high level official meetings and programs. He has delivered lectures and presented papers at many national and international thinktanks, universities, academic institutions and many other forums. He has also published many articles and papers. Being the Chairman of MUSLIM Institute he has organized and supervised many international programmes and activities 